\title{
Is there any association between EBV infection and carotid artery stenosis?
}

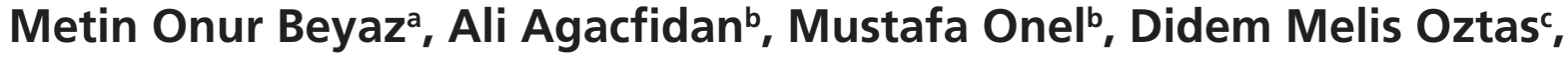 Ibrahim Erdinc ${ }^{d}$, Orhan Rodoplue, Mert Meric ${ }^{f}$, Orcun Unalg, Cenk Conkbayirh, Murat Ugurlucana}

a Department of Cardiovascular Surgery, Istanbul Medipol University Medical Faculty, Istanbul, Turkey

${ }^{b}$ Department of Microbiology, Istanbul University, Istanbul Medical Faculty, Istanbul, Turkey

' Cardiovascular Surgery Clinic, Istanbul Education and Research Hospital, Istanbul, Turkey

d Cardiovascular Surgery Clinic, Izmir Bozyaka Education and Research Hospital, Izmir, Turkey

e Cardiovascular Surgery Clinic, Florence Nightingale Hospital, Istanbul, Turkey

${ }^{f}$ Department of Cardiovascular Surgery, Istanbul University, Istanbul Medical Faculty, Istanbul, Turkey

${ }^{g}$ Cardiovascular Surgery Clinic, Yedikule Chest Diseases and Thoracic Surgery Education and Research Hospital, Istanbul, Turkey

${ }^{h}$ Department of Cardiology, Near East University Medical Faculty, Nicosia, Cyprus

ARTICLE INFO

Article history:

Submitted: 5. 2. 2021

Accepted: 17. 8. 2021

Available online: 22. 9. 2021

Klíčová slova:

Ateroskleróza

EBV

Stenóza karotické tepny

Virová etiologie
SOUHRN

Cíl: Ateroskleróza je hlavním etiologickým faktorem v rozvoji ischemické choroby srdeční, postižení karotických tepen $\mathrm{i}$ ischemické choroby dolních končetin. $V$ naší studii jsme se pokusili prokázat př́tomnost a účinek viru Epsteina-Barrové (Epstein-Barr virus, EBV) na stenózu karotických tepen vedoucí k rozvoji chronického zánětu s tvorbou prozánětlivých cytokinů a vyvolávající aterosklerózu.

Materiál a metody: V období mezi dubnem 2017 a dubnem 2018 bylo na klinice kardiochirurgie lékařské fakulty istanbulské univerzity po podepsání informovaného souhlasu do této studie zařazeno 36 pacientů po endarterektomii karotid. U každého pacienta (dobrovolníka) byly zaznamenány věk, pohlaví, tělesná výška a hmotnost. Ve skupině těchto pacientů bylo $58,3 \%(n=21)$ mužů a $41,7 \%(n=15)$ žen. Byly zaznamenány i komorbidity jako hypertenze a diabetes mellitus.

Výsledky: Nebyl nalezen významný rozdíl v pozitivitě na EBV (DNA) na základě prítomnosti hyperlipidemie, pohlaví a věku. Pozitivita na EBV (DNA) však byla nicméně vyšší (i když ne statisticky významně) u pacientů s komorbiditami, jako jsou hypertenze a diabetes mellitus. Pozitivita na EBV (DNA) byla zjištěna u 42,1 \% pacientů s oboustrannou stenózou karotických tepen a nulová u pacientů bez oboustranné stenózy karotických tepen $(p=0,002)$. Pozitivita na EBV (DNA) byla statisticky významně vyšší u pacientů s oboustrannou stenózou karotických tepen.

Závěr: Domníváme se, že statisticky významně vy̌ší hodnoty pozitivity na EBV (DNA) u pacientů s oboustrannou stenózou karotických tepen by měly podnítit dalši výzkum v oblasti vlivu virové etiologie na rozvoj aterosklerózy; to si však vyžádá další studie.

(c) 2021, ČKS.

ABSTRACT

Objective: Atherosclerosis is the mainly etiologic factor of coronary artery disease, carotid artery disease and peripheral artery disease. In our study, we aimed to show the presence and effect of Epstein-Barr virus (EBV) on the carotid artery stenosis leading chronic inflammatory process by producing pro-inflammatory cytokines and causing atherosclerosis.

Material and methods: Between April 2017 and April 2018, thirty-six patients, who underwent carotid endarterectomy at Department of Cardiovascular Surgery, Istanbul University Istanbul Medical Faculty, are included in this study upon their consent. Each voluntary patient was initially recorded for age, sex, height and weight. Among 36 patients included in the study, 58.3\% $(n=21)$ were male and $41.7 \%(n=15)$ were female. The comorbidities such as hypertension, diabetes mellitus were considered.

Results: There was not significant difference in EBV (DNA) positivity according to hyperlipidemia presence, sex, and age factors. However, the EBV (DNA) positivity was higher in the patients with co-morbidities such as hypertension and diabetes mellitus; no significant difference was detected. EBV (DNA) positivity in patients with bilateral carotid artery stenosis was $42.1 \%$ and it was $0 \%$ in patients without bilateral carotid artery stenosis ( $p: 0,002$ ). The EBV (DNA) positivity was significantly higher in patients with bilateral carotid artery stenosis Conclusion: We believe that our significantly high EBV (DNA) rates in the patients with bilateral carotid artery stenosis may encourage the studies that claim the role of viral etiology on atherosclerosis, however, further studies are needed.
Keywords:

Atherosclerosis

Carotid artery stenosis

EBV

Viral etiology 


\section{Introduction}

Atherosclerosis is the main cause of the cardiovascular and cerebrovascular morbidity, and results from multifactorial etiology. Obesity, hyperlipidemia, diabetes mellitus, hypertension, and smoking are traditional risk factors. ${ }^{1}$ Worldwide the most common cause of death and disability is atherosclerosis and its complications for the cardiovascular system. ${ }^{2}$

There are many reports about supporting chronic inflammation role in atherosclerosis as a result of infectious etiology. Involvement of bacterial and viral agents to the pathways leading to the atherosclerosis has been shown in many experimental animal studies. ${ }^{1}$

Carotid artery stenosis is one of the most common diseases in elderly patients and is the leading cause of stroke and stroke is the third leading cause of death worldwide. ${ }^{3}$ Approximately $87 \%$ of the strokes are ischemic, $10 \%$ due to intracerebral hemorrhage, and 3\% due to subarachnoid hemorrhage..$^{4,5}$

EBV role in the etiopathogenesis of atherosclerosis is as unclear as CMV. It is thought that EBV triggers producing pro-inflammatory cytokines such as interleukin-6 (IL-6) and endothelial cell expression of intercellular adhesion molecule-1 (ICAM-1). Increased levels of these cytokines, TNF- $\alpha$ and IL-6, predict mortality and morbidity. Also, they are observed in atherosclerotic lesions and serum in cardiovascular disease patients. ${ }^{6}$

In our study, we aimed to show the presence and effect of Epstein-Barr virus (EBV) on the carotid artery stenosis leading chronic inflammatory process by producing pro-inflammatory cytokines and causing atherosclerosis.

\section{Patients and methods}

We included 36 patients who underwent carotid endarterectomy (CEA) operation at Department of Cardiovascular Surgery, Istanbul University Istanbul Medical Faculty between April 2017 and April 2018 in this study. The same surgeon (M.U.) operated on 35 patients and the surgery of a remaining one was performed by a different surgeon.

Each voluntary patient was initially recorded for age, sex, height and weight. Among 36 patients included in the study, $58.3 \%(n=21)$ were male and $41.7 \%(n=15)$ were female. $66.7 \%$ of the patients were 65 years old and older with a mean age of $67.5 \pm 9.6$ years and a median age of 68 years (minimum 42 - maximum 85 ).

Body mass index (BMI) was calculated. The comorbidities such as hypertension, diabetes mellitus, and chronic renal failure (CRF) were considered. Patients were questioned for presence of neurological symptoms before operation, bilateral CEA operation necessity, smoking and alcohol use, previous cardiovascular interventions and family history.

Patients with additional immunosuppressive conditions (malignancy, chronic autoimmune disease, AIDS etc.) were excluded from the study. For patients who needed bilateral CEA operation; unilateral atheromatous plaque was preferred.
Carotid artery stenosis rates were revealed by radiological imaging results such as carotid duplex ultrasonography, computerized tomography angiography, magnetic resonance angiography, and subtraction angiography.

Conventional carotid endarterectomy operation technique was preferred for all of the patients. Operations were performed with continuous neurological evaluation during carotid arterial clamping under cervical regional block. Dacron patch was used in all patients.

Following conventional carotid endarterectomy procedure, samples were taken from the patients into the sterile petri dishes and pre-mechanically disintegrated with scalpel. Subsequently, $400 \mu \mathrm{l}$ of tissue lysis solution and $40 \mu$ l of proteinase $\mathrm{K}$ were added to $2 \mathrm{ml}$ of sterile Eppendorf Tubes to perform $56{ }^{\circ} \mathrm{C}$ overnigt tissue disruption Buffer ATL (Cat no: 939011), Proteinase K (Cat no: 19133; qiagen). Quantitation of EBV samples in Green channel was performed by PCR analysis. In the yellow channel, the internal control used during the isolation phase was assessed, which allows us to check the Isolation and PCR stage correctly.

\section{Surgical technique}

Under regional block and local anesthesia, common carotid artery, internal and external carotid arteries were prepared by incision parallel to the sternocleidomastoid muscle. Following systemic heparinization (5000 IU), the arteries were clamped. Prior to arteriotomy, the patient's consciousness and neurological status was evaluated with oral stimulation and contralateral half of the body in response to commands. If neurological disorder was detected, endarterectomy was going to be performed with shunt. Neurological deterioration was not detected in any patients. Internal carotid arteries were reconstructed using Dacron patch material in all patients. In patients with bilateral carotid artery stenosis, the presence of symptoms was considered in decision. Primarily, the symptomatic side was treated; otherwise the more stenotic side was operated. The plaque material was sent to the microbiology laboratory under appropriate conditions for microbiological examination.

\section{EBV DNA analysis}

Clinical specimens obtained from the patients after conventional carotid endarterectomy were first subjected to physical disintegration with the help of a scalpel in sterile petri dishes. After the procedure, the shredded clinical specimens were placed in $20 \mathrm{mg}$ sterile Eppendorf tubes with $400 \mu \mathrm{l}$ of tissue lysis solution (Qiagen, Cat no: 939011), and $40 \mu$ l of proteinase K (Qiagen, Cat no: 19133) was added, in accordance with the kit procedure, to perform overnight incubation at $56{ }^{\circ} \mathrm{C}$. Then, $600 \mu \mathrm{l}$ of AVE solution was added into the Eppendorf Tubes containing the clinical specimens, and EBV DNA extraction was performed. Extraction of the samples was performed using the EZ1 Virus Mini Kit v2.0 (Qiagen cat no:955134). PCR was performed using the Artus EBV QS-RGQ kit (24) (Cat no:4501363) on a Rotorgene Q instrument. Assessment of the results was based on the Rotorgene $\mathrm{Q}$ device in the green channel showing the presence of EBV DNA in clinical specimens and in the yellow channel displaying the internal control for any inhibition in the study. 


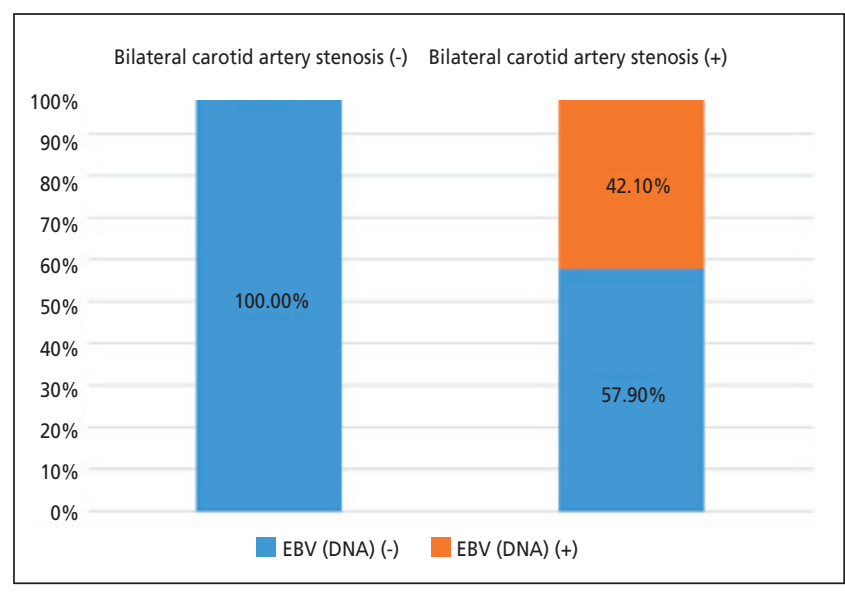

Fig. 1 - EBV (DNA) distribution according to the presence of bilateral carotid artery stenosis.

\section{Statistical analysis}

Statistical Product and Service Solutions (SPSS) software package (version 21.0, SPSS-IBM, Armonk, NY, USA) was used for all analysis at the $95 \%$ confidence level and $p<$ 0.05 significance level. Quantitative variables were reported as the mean and standard deviation (SD); qualitative variables were described as number and percentages. Quantitative variables were analyzed by Friedman Analysis for dependent groups. Subgroup analysis was performed by Wilcoxon Analysis and interpreted by Bonferroni correction. The independent groups were compared with chi-square analysis.

\section{Ethical approvement}

The study was approved by ethical commitee of Istanbul University Istanbul Medical Faculty with 2019/830 number. The microbiological examination was performed in Istanbul University Istanbul Medical Faculty.

\section{Results}

Thirty-six patients were included into the study. 58.3\% (n $=21)$ of the patients were male and $41.7 \%(n=15)$ were female. $66.7 \%$ of the patients had DM, 61.1\% had HT and $55.6 \%$ had hyperlipidemia. $66.7 \%$ of the patients were 65 years and over, with a mean age of $67.5 \pm 9.6$ years and a median age of 68 years (minimum 42 - maximum 85 (Table 1)). Smoking was one of the questioned factors and twenty-four patients were active smokers and eight patients were ex-smokers.

The EBV (DNA) presence in the samples taken from the patients' plaques were examined considering sex, age and comorbidities. EBV (DNA) positivity (25\%) was higher in DM patients than in non-DM patients $(16.7 \%)(p$ : 0.201). Similarly, EBV (DNA) positivity $(25 \%)$ was higher in HT patients than in non-HT patients (18.8\%) ( $p: 0.654)$. However, the EBV (DNA) positivity was higher in the patients with co-morbidities; no significant difference was detected. Also there was not significant difference in EBV (DNA) positivity according to hyperlipidemia presence, sex, and age factors (Table 2 ).

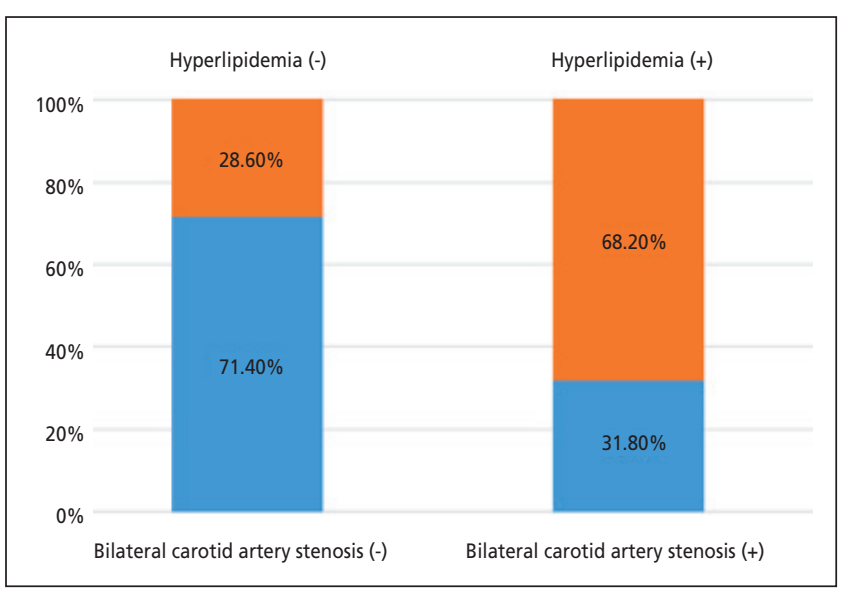

Fig. 2 - Bilateral carotid artery stenosis according to the presence of hyperlipidemia.

\section{Table 1 - Demographic characteristics of the patients}

\begin{tabular}{l|l|l|l}
\hline \multirow{2}{*}{ Gender } & Male & $\mathbf{n}$ & $\%$ \\
\cline { 2 - 4 } & Female & 21 & $(58.3)$ \\
\hline Age* & $<65$ years & 15 & $(41.7)$ \\
\cline { 2 - 4 } & $\geq 65$ years & 24 & $(33.3)$ \\
\hline Diabetes mellitus & & 24 & $(66.7)$ \\
\hline Hypertension & & 22 & $(66.7)$ \\
\hline Hyperlipidemia & & 20 & $(61.1)$ \\
\hline Smoking & & 32 & $(85.6)$ \\
\hline
\end{tabular}

* Mean age 67.5ะ9.6 and median age 68 (min.: 42 max.: 85)

Table 2 - Relationship between EBV (DNA) positivity and gender, age and comorbidities

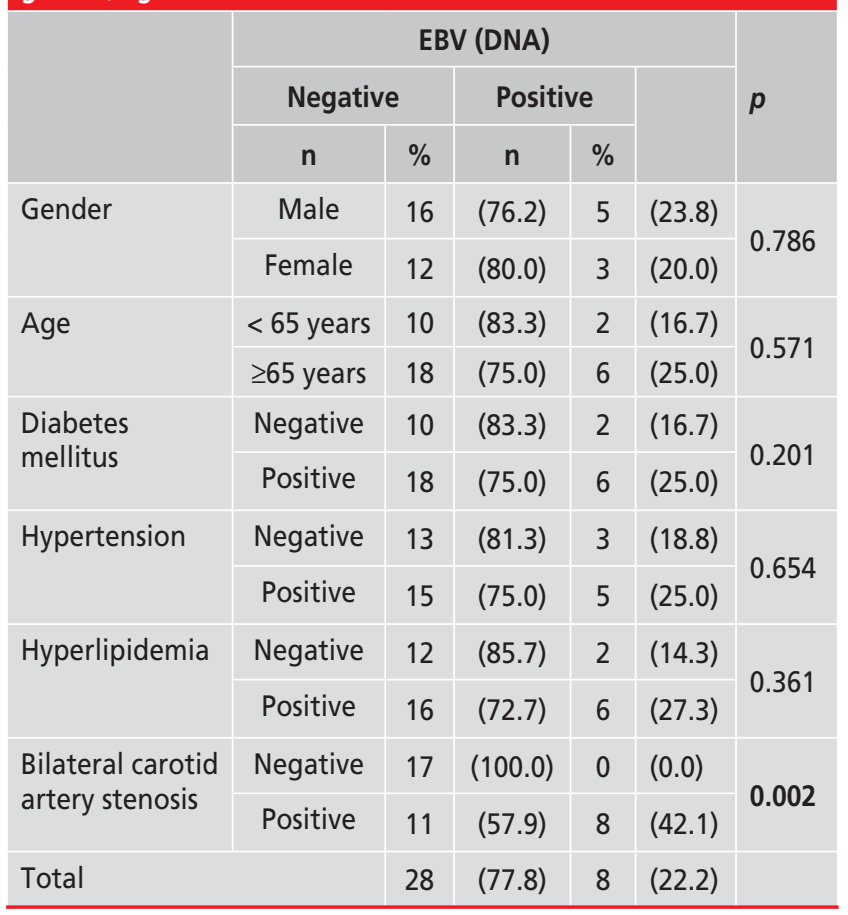


Table 3 - Relationship between bilateral carotid artery stenosis and gender, age and comorbidities

Bilateral carotid artery stenosis

\begin{tabular}{|c|c|c|c|c|c|c|}
\hline & \multirow{2}{*}{\multicolumn{2}{|c|}{ Negative }} & \multirow{2}{*}{\multicolumn{2}{|c|}{ Positive }} & & \multirow{3}{*}{$p$} \\
\hline & & & & & & \\
\hline & $\mathrm{n}$ & $\%$ & $\mathrm{n}$ & $\%$ & & \\
\hline \multirow[t]{2}{*}{ Gender } & Male & 10 & $(47.6)$ & 11 & $(52.4)$ & \multirow[t]{2}{*}{0.955} \\
\hline & Female & 7 & $(46.7)$ & 8 & (53.3) & \\
\hline \multirow[t]{2}{*}{ Age } & $<65$ years & 7 & $(58.3)$ & 5 & $(41.7)$ & \multirow[t]{2}{*}{0.345} \\
\hline & $\geq 65$ years & 10 & $(41.7)$ & 14 & $(58.3)$ & \\
\hline \multirow{2}{*}{$\begin{array}{l}\text { Diabetes mel- } \\
\text { litus }\end{array}$} & Negative & 8 & $(66.7)$ & 4 & (33.3) & \multirow[t]{2}{*}{0.098} \\
\hline & Positive & 9 & (37.5) & 15 & (62.5) & \\
\hline \multirow[t]{2}{*}{ Hypertension } & Negative & 10 & (62.5) & 6 & (37.5) & \multirow[t]{2}{*}{0.101} \\
\hline & Positive & 7 & $(35.0)$ & 13 & $(65.0)$ & \\
\hline \multirow[t]{2}{*}{ Hyperlipidemia } & Negative & 10 & (71.4) & 4 & $(28.6)$ & \multirow[t]{2}{*}{0.020} \\
\hline & Positive & 7 & (31.8) & 15 & $(68.2)$ & \\
\hline
\end{tabular}

When EBV (DNA) positivity was examined depending on the presence of bilateral carotid artery stenosis; the EBV (DNA) positivity in patients with bilateral carotid artery stenosis was $42.1 \%$ and it was $0 \%$ in patients without bilateral carotid artery stenosis ( $p$ : 0.002). The EBV (DNA) positivity was significantly higher in patients with bilateral carotid artery stenosis (Table 2, Fig. 1).

When bilateral carotid artery stenosis presence was examined according to age, sex, hyperlipidemia, diabetes mellitus and hypertension; bilateral carotid artery stenosis was significantly higher in patients with hyperlipidemia (68.2) than the patients without hyperlipidemia (28.6) (p: 0,020) (Table 3, Fig. 2).

\section{Discussion}

Atherosclerosis is the most common cause of coronary artery disease, carotid artery disease, and peripheral artery disease. ${ }^{3}$ Infectious etiology is thought as one of the etiologic factors that lead to atherosclerosis by triggering chronic inflammation. ${ }^{1}$ In literature, there are some studies that have found the prevalence of CMV and EBV $63.3 \%$ and $56.7 \%$, respectively, in the atheromatous plaque samples. Also there are earlier reports that reveal $10-90 \%$ CMV prevalence in atheromatous plaque. On the contrary to this, some authors declared that they were not able to identify CMV in atherosclerotic tissues. ${ }^{1}$ In a study by Shi et al. ${ }^{7}$ the prevalence of EBV was found in a range of $60-80 \%$ in atheromatous plaque samples which agrees with Horvarth et al. $^{8}$ and Priyanka et al.'s ${ }^{1}$ results.

Despite the role of viral infections in the pathogenesis of atherosclerosis is controversial; the role of viral etiology in atherosclerosis has stronger evidences day after day. The studies that have shown influenza vaccination may serve as secondary prevention for coronary events and the relationship between chronic infection of human papilloma virus and the incidence of coronary artery disease are one of the most demonstrating examples of the role of viral mediated atherosclerosis. ${ }^{1}$ The mechanisms that viral infections trigger the pathway of atherosclerosis include cytokins. The viral infection promotes pro-inflammatory cytokine reproduction and these pro-inflammatory cytokines may cause endothelial damage and predispose multiple phases of atherosclerosis. ${ }^{6}$ There are some studies that the level of CMV- and EBV-specific antibodies are found increased in vascular disease patients. ${ }^{9}$ Following reactivation of latent virus, EBV encodes an enzyme, deoxyuridine triphosphate nucleotidohydrolase (dUTPase). It is shown that dUTPase induces peripheral blood monocytes to produce pro-inflammatory cytokines. ${ }^{1}$ The reason of while some studies could show the EBV presentation in atherosclerotic lesions; the others of them could not detect any viral pathology is maybe the technical difficulties to detect low viral load.

When the role of viral etiology on atherosclerotic diseases hass gained importance; the association between infectious agents and calcified aortic valve stenosis has been evaluated in a limited number of studies. Because, although the degenerative aortic stenosis was thought to have occurred as a result of the passive accumulation of calcium, the recent studies have shown that the etiology of the aortic valve diseases has similar pathophysiology with vascular atherosclerosis. However there has been no evidence for the presence of EBV in stenotic aortic valves. ${ }^{10}$

In our study when EBV (DNA) positivity was examined according to the presence of bilateral carotid artery stenosis; the EBV (DNA) positivity in patients with bilateral carotid artery stenosis was $42.1 \%$ and it was $0 \%$ in patients without bilateral carotid artery stenosis ( $p: 0.002)$. The EBV (DNA) positivity was significantly higher in patients with bilateral carotid artery stenosis. Bilateral carotid artery stenosis was significantly higher in patients with hyperlipidemia (68.2) than the patients without hyperlipidemia (28.6) ( $p$ : 0.020). But there was not significant difference in EBV (DNA) positivity according to hyperlipidemia presence, sex, and age factors.

The limitations of our study include a limited number of patients and single center experiences. Although we have found higher EBV (DNA) positivity in the patients with bilateral carotid artery stenosis and higher bilateral carotid artery diseases in patients with hyperlipidemia; we could not detect significant difference in EBV (DNA) positivity according to hyperlipidemia presence. Besides we could not clarify the role of EBV (DNA) in the pathway leading to atherosclerosis.

In conclusion, we believe that our significantly high EBV (DNA) rates in the patients with bilateral carotid artery stenosis may encourage the studies that claims the role of viral etiology on atherosclerosis, however further studies are needed.

\section{Conflict of interest}

None.

\section{Author contributions}

MOB, AA, MO, DMO, IE, OR, MM, OU, CC, MU acted in study design. MOB is the responsible author for data integrity, data collection and analysis. Manuscript was primarily written by MOB. AA, MO, DMO, IE, OR, MM, OU, CC, MU helped with writing and linguistic revision of the paper. 


\section{References}

1. Priyanka S, Kaarthikeyan G, Nadathur JD, et al. Detection of cytomegalovirus, Epstein-Barr virus, and Torque Teno virus in subgingival and atheromatous plaques of cardiac patients with chronic periodontitis. J Indian Soc Periodontol 2017;21:456460.

2. Badimon $\mathrm{L}$, Vilahur $\mathrm{G}$. Thrombosis formation on atherosclerotic lesions and plaque rupture. J Intern Med 2014;276:618-632.

3. Ugurlucan M, Akay HT, Erdinc I, et al. Anticoagulation strategy in patients with atrial fibrillation after carotid endarterectomy. Acta Chir Belg 2019;119(4):209-216.

4. Roger VL, Go AS,Lloyd-Jones DM,et al: Heart disease and stroke statistics - 2012 update: a report from the American Heart Association. Circulation 125:e2-e220,2012.

5. Beyaz MO, Ugurlucan M, Oztas DM, et al. Evaluation of the relationship between plaque formation leading to symptomatic carotid artery stenosis and cytomegalovirus by investigating the virus DNA.Arch Med Sci Atheroscler Dis 2019;4:e19-e24.
6. Waldman WJ, Williams MV Jr, Lemeshow S, et al. Epstein-Barr virus-encoded dUTPase enhances proinflammatory cytokine production by macrophages in contact with endothelial cells: evidence for depression-induced atherosclerotic risk. Brain Behav Immun 2008;22:215-223.

7. Shi Y, Tokunaga O. Herpesvirus (HSV-1, EBV and CMV) infections in atherosclerotic compared with nonatherosclerotic aortic tissue. Pathol Int 2002;52:31-39.

8. Horváth R, Cerný J, Benedík Jr J, et al. The possible role of human cytomegalovirus (HCMV) in the origin of atherosclerosis. J Clin Virol 2000;16:17-24.

9. Al-Ghamdi A. Role of herpes simplex virus-1, cytomegalovirus and Epstein-Barr virus in atherosclerosis. Pak J Pharm Sci 2012;25:89-97.

10. Bayram A, Erdoğan MB, Ekşi F, Yamak B. Demonstration of Chlamydophila pneumoniae, Mycoplasma pneumoniae, Cytomegalovirus, and Epstein-Barr virus in atherosclerotic coronary arteries, nonrheumatic calcific aortic and rheumatic stenotic mitral valves by polymerase chain reaction. Anadolu Kardiyol Derg 2011;11:237-243. 